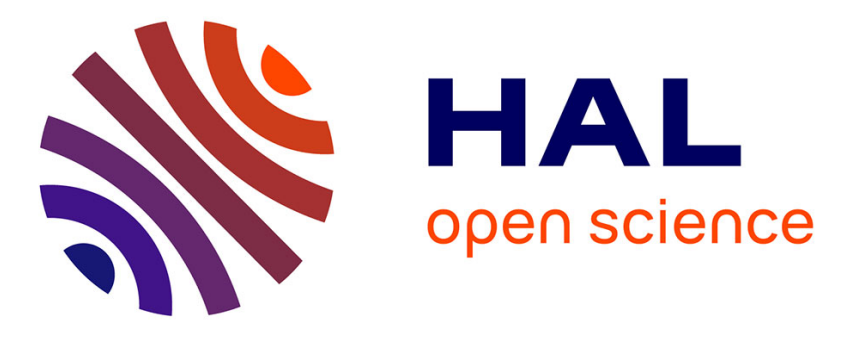

\title{
Molecular pharmacology and antitumor activity of in several human cancer cell lines
}

\author{
Juan F.M. Leal, Verónica García-Hernández, Victoria Moneo, Alberto \\ Domingo, Juan Antonio Bueren-Calabuig, Ana Negri, Federico Gago, María \\ José Guillén-Navarro, Pablo Avilés, Carmen Cuevas, et al.
}

\section{To cite this version:}

Juan F.M. Leal, Verónica García-Hernández, Victoria Moneo, Alberto Domingo, Juan Antonio BuerenCalabuig, et al.. Molecular pharmacology and antitumor activity of in several human cancer cell lines. Biochemical Pharmacology, 2009, 78 (2), pp.162. 10.1016/j.bcp.2009.04.003 . hal-00493513

\section{HAL Id: hal-00493513 https://hal.science/hal-00493513}

Submitted on 19 Jun 2010

HAL is a multi-disciplinary open access archive for the deposit and dissemination of scientific research documents, whether they are published or not. The documents may come from teaching and research institutions in France or abroad, or from public or private research centers.
L'archive ouverte pluridisciplinaire HAL, est destinée au dépôt et à la diffusion de documents scientifiques de niveau recherche, publiés ou non, émanant des établissements d'enseignement et de recherche français ou étrangers, des laboratoires publics ou privés. 


\section{Accepted Manuscript}

Title: Molecular pharmacology and antitumor activity of Zalypsis $^{\circledR}$ in several human cancer cell lines

Authors: Juan F.M. Leal, Verónica García-Hernández, Victoria Moneo, Alberto Domingo, Juan Antonio Bueren-Calabuig, Ana Negri, Federico Gago, María José Guillén-Navarro, Pablo

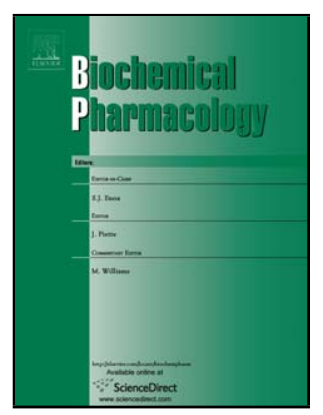
Avilés, Carmen Cuevas, Luis Francisco García-Fernández, Carlos María Galmarini

PII: S0006-2952(09)00263-9

DOI: doi:10.1016/j.bcp.2009.04.003

Reference: BCP 10141

To appear in: $\quad B C P$

Received date: $\quad$ 13-2-2009

Revised date: $\quad$ 2-4-2009

Accepted date: $\quad 6-4-2009$

Please cite this article as: Leal JFM, García-Hernández V, Moneo V, Domingo A, Bueren-Calabuig JA, Negri A, Gago F, Guillén-Navarro MJ, Avilés P, Cuevas C, García-Fernández LF, Galmarini CM, Molecular pharmacology and antitumor activity of Zalypsis ${ }^{\circledR}$ in several human cancer cell lines, Biochemical Pharmacology (2008), doi:10.1016/j.bcp.2009.04.003

This is a PDF file of an unedited manuscript that has been accepted for publication. As a service to our customers we are providing this early version of the manuscript. The manuscript will undergo copyediting, typesetting, and review of the resulting proof before it is published in its final form. Please note that during the production process errors may be discovered which could affect the content, and all legal disclaimers that apply to the journal pertain. 


\section{Molecular pharmacology and antitumor activity of Zalypsis $\AA$}

in several human cancer cell lines. (Leal et al. BCP-D-09-00162-Rev1)

\section{Zalypsis@}

\section{Molecular pharmacology}

- Formation of DNA adducts

- Detection of most favorable DNA triplets for covalent adduct formation

- Rationalization of these triplets by molecular modeling

- Induction of double-strand DNA breaks

-Triggering of S-phase accumulation

-Induction of apoptotic cell death

\section{Antitumor activity}

In vitro activity

24 cancer cell lines

Mean IC50 value: $7 \mathrm{nM}$

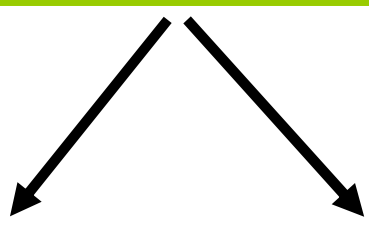

In vivo activity 4 xenograft tumors Significant tumor growth inhibition 


\section{Molecular pharmacology and antitumor activity of Zalypsis ${ }^{\circledR}$ in several human cancer cell lines}

Juan F.M. Leala, Verónica García-Hernández ${ }^{b}$, Victoria Moneoa, Alberto Domingob, Juan Antonio Bueren-CalabuigC, Ana Negric, Federico Gagoc, María José Guillén-Navarroa, Pablo Avilésa , Carmen Cuevasa ${ }^{a}$, Luis Francisco García-Fernándeza, Carlos María Galmarinia ${ }^{*}$

a Cell Biology Department, Pharmamar, Spain

b Department of Biochemistry and Molecular Biology, University of Alcalá, Spain

C Department of Pharmacology, University of Alcalá, Spain

Running title: Antitumor activity of Zalypsis ${ }^{\circledR}$

${ }^{*}$ Correspondence to:

Carlos M. Galmarini, MD, PhD

Manager

Cell Biology Department

Avda. de los Reyes, 1

28770 Colmenar Viejo

Madrid, Spain

E-mail: cgalmarini@pharmamar.com

Phone: \#34-91-846 6158

Fax: \#34-91-846 6001 


\section{Abstract}

Zalypsis $^{\circledR}$ is a new synthetic alkaloid tetrahydroisoquinoline antibiotic that has a reactive carbinolamine group. This functionality can lead to formation of a covalent bond with the amino group of selected guanines in the DNA double helix, both in the absence and in the presence of methylated cytosines. The resulting complex is additionally stabilized by the establishment of one or more hydrogen bonds with adjacent nucleotides in the opposite strand as well as by van der Waals interactions within the minor groove. Fluorescence-based thermal denaturation experiments demonstrated that the most favorable DNA triplets for covalent adduct formation are AGG, GGC, AGC, CGG and TGG, and these preferences could be rationalized on the basis of molecular modeling results. Zalypsis ${ }^{\circledR}$-DNA adducts eventually give rise to double-strand breaks, triggering S-phase accumulation and apoptotic cell death. The potent cytotoxic activity of Zalypsis ${ }^{\circledR}$ was ascertained in a 24 cell line panel. The mean $I_{50}$ value was $7 \mathrm{nM}$ and leukemia and stomach tumor cell lines were amongst the most sensitive. Zalypsis ${ }^{\circledR}$ administration in four murine xenograft models of human cancer demonstrates significant tumor growth inhibition that is highest in the Hs746t gastric cancer cell line with no weight loss of treated animals. Taken together, these results indicate that the potent antitumor activity of Zalypsis ${ }^{\circledR}$ supports its current development in the clinic as an anticancer agent.

Key words: Antineoplastic agents, Tetrahydroisoquinolines, DNA breaks, apoptosis 


\section{Introduction}

Zalypsis $^{\circledR}$ (Figure $1 \mathrm{~A}$ ) is a new synthetic dimeric isoquinoline alkaloid that is currently in Phase I clinical development for the treatment of solid tumors and hematological malignancies. This compound is structurally related to jorumycin, a natural compound isolated from the skin and mucus of the Pacific nudibranch Jorunna funebris [1], and also to renieramycins isolated from sponges and tunicates [2, 3], safracins and saframycins isolated from bacteria and marine sponges [4], and ecteinascidins isolated from marine tunicates [5]. These carbinolaminecontaining compounds react, through an iminium intermediate that is generated by dehydration $[4,6-8]$, with the exocyclic amino group of selected guanines in the minor groove of DNA. The resulting adduct is additionally stabilized through the establishment of van der Waals interactions and one or more hydrogen bonds with neighboring nucleotides in the opposite strand of the DNA double helix [8,9], thus creating the equivalent to a functional interstrand crosslink [10] that can lead to strong inhibition of the early phases of transcription [11, 12].

In this study we characterized both molecular interactions with the DNA and the cytotoxic activity of Zalypsis ${ }^{\circledR}$ in an attempt to shed light into its mechanism of antitumor action. The DNA binding characteristics were studied using a combination of electrophoretic mobility shift assays in polyacrylamide gels and a fluorescence-based method that employs tailor-made oligonucleotides. We also looked at the type of DNA damage subsequently generated in living cells as a consequence of Zalypsis ${ }^{\circledR}$-DNA adduct formation and whether cell cycle arrest and cell death induced by this compound mechanistically depend on caspase activation. Then, in vitro cytotoxic activity was evaluated in a panel of 24 different cancer cell lines. Finally, the in vivo antitumor activity of Zalypsis ${ }^{\circledR}$ was investigated using several murine xenograft models of human prostate, stomach, bladder and pancreas carcinomas.

\section{Materials and Methods}


2.1. Drugs. Zalypsis ${ }^{\circledR}$ is a Pharmamar SAU proprietary drug synthesized at our facilities. ET745 is a synthetic isoquinoline derived from trabectedin (ET-743) that lacks the carbinolamine group (Supplementary Material, Figure 1) and does not alkylate DNA [13]. Z-Vad-fmk is a pancaspase inhibitor purchased from Sigma (St Louis, MO, USA).

2.2. DNA electrophoretic mobility shift assay. The binding assays were performed either with a 250-bp PCR product from the human adiponectin gene or with a double-stranded oligonucleotide (ds-oligo) synthesized by Sigma (St Louis, MO, USA). Briefly, appropriate concentrations of the compound were added at $25^{\circ} \mathrm{C}$ during 1 hour to 250 -bp DNA or ds-oligo. Then, DNA was subjected to electrophoresis in a $2 \%(\mathrm{w} / \mathrm{v})$ agarose/TAE gel, stained with 1 $\mu \mathrm{g} / \mathrm{mL}$ ethidium bromide and photographed. The sequences of the oligonucleotides used in the assay are the following: NonMeth-Fw 5'-TAAATATTTCCGGATATAATTAT-3'; NonMeth-Rev 5'ATAATTATATCCGGAAATATTTA-3'; Meth-Fw 5'-TAAATATTTCMeCGGATATAATTAT-3'; Meth-Rev 5'-ATAATTATATCMeCGGAAATATTTA-3'.

2.3. DNA melting assay. Synthetic oligodeoxynucleotides with one strand 5'-end-labeled with the fluorophore 6-carboxyfluorescein (6-FAM, F) and the complementary strand 3'-end-labeled with the quencher tetramethylrhodamine (TAMRA, Q) were synthesized at Bonsai Technologies (Madrid, Spain) (Supplementary Table 1). For the experiments, we followed the methodology previously described in a 7500 Fast Real-Time PCR System (ABI Prism, Applied Biosystems, Foster City, CA, USA) [10,14]. The raw data obtained were analyzed to estimate the increases in melting temperatures $\left(\Delta \mathrm{T}_{\mathrm{m}}\right)$ brought about by drug binding as well as the ligand concentration that produces half the maximal change in melting temperature $\left(\mathrm{C}_{50}\right)$. The inverse of this value $\left(1 / C_{50}\right)$ was taken as a measure of the relative DNA binding affinity. We additionally used the parameter $\Delta \mathrm{T}_{\mathrm{m}}(\max )$ to reflect the relative stability of the DNA-ligand complexes [14]. The complete analysis was carried out using an in-house developed Visual Basic Application running on Microsoft Excel (Microsoft, Redmond, WA, USA). 
2.4. Computational methods. We studied in atomic detail the feasibility of achieving the geometries required to activate dehydration of the carbinolamine prior to the nucleophilic attack that leads to covalent bond formation. To this end, the initial structures of the precovalent complexes between Zalypsis ${ }^{\circledR}$ and a series of oligonucleotides of general sequence 5'd(ATAATAXYZATAATA)/5'-d(TATTATZ'Y'X'TATTAT), where XYZ/Z'Y'X' stands for AGA/TCT, A $\underline{G} / C C T$ and $A \underline{G C} / G C T$, were built as previously reported for trabectedin [15]. The complexes were then refined using energy minimization techniques in the AMBER force field and their stability was studied by means of 5 ns of unrestrained molecular dynamics simulations in an explicit water box using the same conditions as described previously.

2.5. Cell culture and cytotoxicity. All the tumor cell lines used in this study were obtained from the American Type Culture Collection (ATCC, Rockville, MD, USA). For the cytotoxicity experiments, cells were seeded in 96-well trays. Serial dilutions of the compound dissolved in dimethyl sulfoxide (DMSO) were prepared and added to the cells in fresh medium, in triplicates. Exposure to the compounds was maintained during 72 hours. Then 3-(4,5-dimethylthiazol-2-yl)2,5-diphenyltetrazolium bromide (MTT) (Sigma, St Louis, MO, USA) was added to the cells and formazan crystals dissolved in DMSO. Absorbance at $540 \mathrm{nM}$ was measured with a POLARStar Omega Reader (BMG Labtech, Offenburg, Germany). Determination of $\mathrm{IC}_{50}$ values was performed by iterative non-linear curve fitting with the Prism 5.0 statistical software (GraphPad, La Jolla, CA, USA). The data presented are the average of three independent experiments performed in triplicate.

2.6. Fluorescent microscopy. Cells were treated with the appropriate concentration of Zalypsis $^{\circledR}$ during 6 hours, washed out and cultured for 18 additional hours. Cells were then fixed (4\% paraformaldehyde), permeabilized $(0.5 \%$ Triton X-100) and incubated with the primary anti$\mathrm{y}-\mathrm{H} 2 \mathrm{AX}$ monoclonal antibody (Upstate, Temecula, $\mathrm{CA}$ ) for $1 \mathrm{~h}$ at $37^{\circ} \mathrm{C}$. Then cells were washed and incubated with the secondary anti-mouse AlexaFluor 594 (Invitrogen, Carlsbad, CA, USA) 
for 30 min at $37^{\circ} \mathrm{C}$. Finally the slides were incubated with Hoesch 33342 (Sigma, St Louis, MO, USA) and mounted with Mowiol mounting medium. Pictures were taken with a Leica DM IRM fluorescence microscope equipped with a 100x oil immersion objective and a DFC 340 FX digital camera (Leica, Wetzlar, Germany).

2.7. Comet Assay. For the determination of double-strand breaks (DSBs) a single cell gel electrophoresis assay was used (Trevigen's CometAssay ${ }^{\top \mathrm{M}}$ ), following the manufacturer's instructions after treatment of cells for 12 hours with the appropriate concentration of Zalypsis ${ }^{\circledR}$. Pictures were taken with a Leica DM IRM fluorescence microscope equipped with a DFC 340 FX digital camera (Leica, Wetzlar, Germany). Quantitation of the DNA in the tails of the comets was performed with Adobe Photoshop CS3 (Adobe Systems Incorporated, San Jose, CA, USA). For each condition 30 cells were analyzed, and the experiments were repeated several times.

2.8. Cell cycle analysis. For the cell cycle experiments, cells were treated with the appropriate amount of the compound for $24 \mathrm{~h}$, and then stained with $0.4 \mu \mathrm{g} / \mathrm{ml}$ propidium iodide. Samples were analyzed with a FACScalibur flow cytometer (Beckton and Dickinson, Franklin Lakes, NJ, USA) and the FlowJo7 cytometry analysis software.

2.9. Apoptosis. For the chromatin condensation assay, cells were treated with the appropriate amount of the compound for 24 hours and stained with DAPI. Early apoptotic cells show chromatin condensation that was assessed with a DM IRM microscope (Leica, Wetzlar, Germany). For the M30-Apoptosense solid-phase sandwich enzyme immunoassay (Peviva, Bromma, Sweden), the kit's instructions were followed. Briefly, cells were exposed to the appropriate concentration of the compound for 24 hours. Cells lysates were obtained and transferred to an assay well, M30 HRP conjugate added and incubated for 4 hours. Once the antigen-M30 was bound to the M5-coated surface of the wells, they were extensively washed and incubated with TMB substrate in the dark for 20 minutes. Finally, the reaction was stopped 
with the addition of a stop solution and plates were read at $450 \mathrm{nM}$ within 30 minutes with a Victor3 platform (Perkin Elmer).

2.10. Western Blot assays. For immunoblotting, cells were treated with the appropriate concentration of the compound for 24 hours and lysed with RIPA lysis buffer. Protein content was determined by the modified Bradford method. Samples were separated in $7.5 \%$ SDSPAGE, transferred onto an Immobilon-P membrane. Then, membranes were incubated with the appropriate primary antibody $1 \mathrm{~h}$, washed and incubated with the secondary antibody. Finally protein was visualized using the ECL System (GE Healthcare, Fairfield, CT, USA). We used anti-PARP rabbit polyclonal, anti-p53FL rabbit polyclonal and anti-p21/WAF1 rabbit polyclonal antibodies from Santa Cruz (Santa Cruz, CA, USA), and an anti-a-tubulin monoclonal antibody from Sigma (St Louis, MO, USA). Secondary antibodies were HRP-conjugated goat anti-rabbit secondary antibody (R\&D Minneapolis, MN, USA) and HRP-conjugated goat anti-mouse secondary antibody (Santa Cruz, CA, USA).

2.11. Antitumor activity in xenograft murine models. Four to six weeks-old athymic $n u / n u$ mice (Harlan Sprague Dawley, Madison, WI, USA) were s.c. xenografted into their right flank with ca. $0.5-1 \times 10^{7}$ cells in $0.2 \mathrm{~mL}$ of a mixture (50:50; v:v) of Matrigel basement membrane matrix (Beckton Dickinson, Frankin Lakes, NJ, USA) and serum-free medium. When tumors reached ca. $150 \mathrm{~mm}^{3}$, mice were randomly assigned into treatment or control groups. Zalypsis ${ }^{\circledR}$ was intravenously administered either in 3 consecutive weekly doses $(0.9 \mathrm{mg} / \mathrm{kg} /$ day $)$ or in 2 cycles of 5 consecutive daily doses $(0.3 \mathrm{mg} / \mathrm{kg} / \mathrm{day})$ in pancreas or in breast and prostate xenograft studies, respectively. Control animals received an equal volume of vehicle. Caliper measurements of the tumor diameters were done twice weekly and tumor volumes calculated according to the following formula: $(a \cdot b)^{2} / 2$, where $a$ and $b$ were the longest and shortest diameters, respectively. Animals were humanely euthanized, according to Institutional Animal Care and Use Committee of PharmaMar, Inc. (Cambridge, MA, USA) guidelines, when their 
tumors reached $3,000 \mathrm{~mm}^{3}$ or if significant toxicity (e.g., severe body weight reduction) was observed. Differences in tumor volumes between treated and control groups were evaluated using the unpaired t-Test. Statistical significance was defined as $p<0.05$. Statistical analyses were performed by LabCat ${ }^{\circledR}$ v8.0 SP1 (Innovative Programming Associates, Inc. NJ, USA). All animal studies were conducted under approval from an IACUC in an AAALAC accredited animal facility.

\section{Results}

3.1. Zalypsis ${ }^{\circledR}$ binds covalently to DNA. The mechanism of action of Zalypsis ${ }^{\circledR}$ is expected to rely on the alkylation of selected guanines in the DNA double helix. Thus, we investigated its binding to DNA by means of band shift assays that allow the qualitative assessment of the molecular weight increase of Zalypsis ${ }^{\circledR}$-DNA adducts. Figure 1B shows a typical band shift experiment using increasing amounts of Zalypsis ${ }^{\circledR}$ in order to saturate the 250 -bp DNA probe with the compound. ET-745, which lacks the crucial hydroxyl group required for activation and covalent DNA modification, was used as a negative control (supplementary Figure 1). As expected, Zalypsis ${ }^{\circledR}$ bound to naked DNA and delayed its electrophoretic migration in the gel. Although $1 \mu \mathrm{M}$ of Zalypsis ${ }^{\circledR}$ was enough to produce a slight delay in band migration, DNA saturation required $\sim 15 \mu \mathrm{M}$ of the compound.

We further assessed whether Zalypsis ${ }^{\circledR}$ could alkylate methylated DNA, using a ds-oligo containing a methylated cytosine in the sequence meCGG. Figure $1 \mathrm{C}$ shows the result of a typical experiment. Zalypsis ${ }^{\circledR}$ bound to methylated and unmethylated CGG sequences with similar efficiencies, suggesting that methylation of the cytosine in a $\mathrm{CpG}$ sequence context in the major groove does not interfere with guanine modification in the DNA minor groove.

3.2. Zalypsis ${ }^{\circledR}$ binds to guanines in selected DNA triplets. To investigate the ability of Zalypsis $^{\circledR}$ to stabilize the double helix, we designed several fluorophore-labeled oligonucleotides encompassing most of the possible DNA triplet combinations involving a central guanine 
(Supplementary Table 1). Figure 2A summarizes the results of the DNA melting experiments. The average $1 / \mathrm{C}_{50}$ and $\Delta \mathrm{T}_{\mathrm{m}}(\max )$ values for Zalypsis ${ }^{\circledR}$ were $\sim 0.6 \mu \mathrm{M}^{-1}$ and $\sim 10{ }^{\circ} \mathrm{C}$, respectively. There were differences in the affinity of Zalypsis ${ }^{\circledR}$ for the different triplets assayed, with the highest affinity being observed for GGC, AGC, AGG and TGG triplets, and the lowest, almost negligible, being displayed by the CGA triplet. Nonetheless, some of the selected triplets (e.g. AGC or AGG) do not provide a good binding site if embedded in an alternative sequence context (e.g. AGCA vs. AGCG and AGGA vs. AGGG). On the other hand, the highest stabilities were observed for adducts formed with the oligos containing the triplets AGA, TGT, AGG, GGC and TGG. Thus, according the affinity indicator $1 / C_{50}$, the most favorable triplets for Zalypsis ${ }^{\circledR}$ bonding to DNA appear to be AGG, GGC, AGC, CGG and TGG whereas the thermal stability of the DNA-adduct involving an AGA or TGT site is slightly above average and those involving CGC, CGT, GGT and CGA sites are well below average.

3.3. Molecular modeling data. The molecular models of the equilibrated Zalypsis ${ }^{\circledR}$-DNA precovalent complexes in aqueous solution provided a rationale for the distinct binding of the drug to three representative central triplets that provide good (AGC), intermediate (AGG) or poor (AGA) binding sites for this drug, the only difference among them being the nature of the base pair on the 3'-side of the guanine that will undergo alkylation. As shown in Table 2, the geometry required for nucleophilic attack of the exocyclic amino group of the central guanine (G8) at the carbinolamine of the drug (C21) was rapidly attained in all cases, as assessed by an interatomic distance of less than $4 \AA$ between the two reactive atoms. Likewise, the carbinol $\mathrm{OH}$ was seen to act as a hydrogen bond acceptor from N2(G8) and as a hydrogen bond donor to $\mathrm{O} 2$ in $\mathrm{C} 21$, that is, the cytosine pairing with G8 (Figure 2B). These findings are consistent with the fact that Zalypsis ${ }^{\circledR}$ is able to react with these triplet sites, and the geometry that we find in these precovalent complexes lends strong support to the proposal that the latter hydrogen bond weakens the N12-H12 covalent bond, thus facilitating transfer of the $\mathrm{H} 12$ proton to the carbinol 
$\mathrm{OH}$, whereas the first hydrogen bond debilitates the $\mathrm{C} 21-\mathrm{OH}$ bond, thus favoring the exit of the water molecule. On the other hand, the protonated N12 of Zalypsis ${ }^{\circledR}$ remained hydrogenbonded to the $\mathrm{O} 2$ acceptor atom of T22 in the AGG and AGC triplets but not in the AGA triplet (Figure $2 \mathrm{C}$ ). This finding, together with the fact that AGA cannot provide a hydrogen-bonding partner to the methylenedioxy oxygen facing the minor groove may account for the fact that AGA is a poorer binding site even though the DNA in the resulting complex is stabilized to a greater extent than those containing the other sequence contexts studied (Figure 2A). When this hydrogen-bonding partner is found, as is the case for the AGC and AGG sequences which possess the amino group of either G20 or G9, respectively, the additional hydrogen bond formed (Figures $2 \mathrm{~B}$ and $2 \mathrm{C}$ ) facilitates the full insertion of the drug into the minor groove and leads to enhanced reactivity. As regards the small stabilization brought about by Zalypsis ${ }^{\circledR}$ on the CGA-containing oligonucleotide, this can be rationalized by proposing that it arises only from the precovalent complex, which cannot evolve into a covalent adduct because of an incorrect geometry for attack (14).

\subsection{The initial Zalypsis ${ }^{\circledR}$-DNA adducts eventually give rise to double-strand breaks} (DSBs) in living cells. We analyzed the formation of $\mathrm{Y}-\mathrm{H} 2 \mathrm{AX}$ foci as a surrogate indicator of DSB formation $[16,17]$. Figure 3A shows typical results of MCF7 and A549 cells treated with Zalypsis ${ }^{\circledR}$ for $6 \mathrm{~h}$ at the indicated concentrations. At $5 \mathrm{nM}$, only a few MCF7 or A549 cells showed $\mathrm{y}-\mathrm{H} 2 \mathrm{AX}$ staining and, in the positive cells, few foci were visible (data not shown). In contrast, at $25 \mathrm{nM}$, most of the cells were stained for $\mathrm{y}-\mathrm{H} 2 \mathrm{AX}$ and each of the positive cells carried a large number of foci, indicating that several DSBs per cell were induced at this drug concentration (Figure 3A). At $100 \mathrm{nM}$, nearly every single cell stained positive for $\mathrm{Y}-\mathrm{H} 2 \mathrm{AX}$, with a large number of foci per nucleus, again an indication of extensive DNA damage and induction of numerous DSBs (data not shown). 
Zalypsis ${ }^{\circledR}$-dependent formation of DSBs was additionally evaluated using the comet assay, which provides a direct measurement of damaged DNA. Both A549 and MCF7 cell lines were treated with Zalypsis ${ }^{\circledR}$ at 10 and $100 \mathrm{nM}$ for 24 hours and the percentage of the total DNA that was in the tail of the comets was measured. A typical comet assay result (Figure 3B) shows a clear concentration-dependent increase in DSBs in both cell lines following treatment with Zalypsis $^{\circledR}$. The use of Mann-Whitney $U$ test demonstrated that differences between each treated-measure against the baseline were statistically significant.

3.5. Zalypsis ${ }^{\circledR}$-treated cells accumulate in S-phase. Table 2 summarizes the results of the assessment of possible cell cycle perturbations after $24 \mathrm{~h}$ of exposure to Zalypsis ${ }^{\circledR}$. At both low (15 nM) and high (150 nM) drug concentrations there was a clear increase of the S-phase population in A549 (lung), HT29 (colon) and MDA-MB-231 (breast) cancer cells. Of note, the Sphase accumulation was higher at $15 \mathrm{nM}$, probably due to a higher cell survival. In IGROV-1 cells we did not observe any S-phase accumulation, most likely due to the extensive cell death induced by the compound at both concentrations after $24 \mathrm{~h}$ treatment (data not shown).

3.6. Zalypsis ${ }^{\circledR}$ induces apoptosis in tumor cells. Since the antitumor mechanism of action of DNA-damaging agents is known to involve induction of apoptosis [18], we investigated whether Zalypsis ${ }^{\circledR}$ treatment was able to induce a canonical apoptosis response in tumor cells. Firstly, we determined whether the drug was able to generate late apoptosis by detecting the flowcytometric subG ${ }_{1}$ cell population (Table 2). A549 and HT-29 cell treatment resulted in an increase in the subG 1 population. On the other hand, MDA-MB-231 cells died with a slower kinetics while IGROV-1 cells died faster (Table 2). These data indicate that the percentage of cells entering the sub- $\mathrm{G}_{1}$ peak after 24 hours of treatment with Zalypsis ${ }^{\circledR}$ was cell type- and concentration-dependent. After treatment of MCF7 and A549 cells with $100 \mathrm{nM}$ Zalypsis ${ }^{\circledR}$ for 24 
hours, an apoptotic nuclear morphology with strong chromatin condensation was clearly visible in fluorescent microscopy in both cell types (data not shown).

We further analyzed the onset of apoptosis using a commercially available solid-phase sandwich enzyme immunoassay that detects the caspase cleavage of cytokeratin-18 as a sensitive and specific marker of early canonical apoptosis [19]. Treatment with $100 \mathrm{nM}$ Zalypsis ${ }^{\circledR}$ induced a marked increase of the apoptosis-related CK-18 Asp396 epitope in A549 cells. Moreover, simultaneous treatment with the pan-caspase inhibitor Z-VAD-fmk strongly reversed this effect (Figure 3C), which clearly indicates that the pro-apoptotic effect of Zalypsis ${ }^{\circledR}$ was dependent on caspase activity.

Finally, we studied the caspase-dependent cleavage of the nuclear protein PARP as a marker of canonical apoptosis. The p85 band, generated through proteolytic cleavage of p116 PARP by activated caspases, was clearly visible as early as 6 hours after the treatment of MCF7 and A549 cells with $100 \mathrm{nM}$ Zalypsis $^{\circledR}$ (Figure 3D). After 48 hours of treatment a considerable proportion of the PARP protein had already been cleaved by caspases, indicating that most of the cells were undergoing canonical apoptosis.

3.7. Zalypsis ${ }^{\circledR}$ shows a potent cytotoxic activity. The in vitro cytotoxicity of Zalypsis ${ }^{\circledR}$ was determined using a panel of 24 tumor cell lines that represent eleven relevant types of human cancer (Table 1). Most of the cell lines were very sensitive to Zalypsis ${ }^{\circledR}$ treatment, with $\mathrm{IC}_{50}$ values in the low nanomolar range. The panel average $\mathrm{IC}_{50}$ was $\sim 7 \mathrm{nM}$, with MOLT-4 (acute lymphoblastic leukemia) cells showing the lowest $\mathrm{IC}_{50}$ and $\mathrm{CAKI}-1$ (renal carcinoma) and HCT116 (colon carcinoma) cells presenting the highest $\mathrm{IC}_{50} \mathrm{~S}$ in the mid-nanomolar range.

\subsection{Zalypsis ${ }^{\circledR}$ exhibits in vivo antitumor activity in xenograft murine models. We} performed xenograft studies to test whether the cytotoxicity of Zalypsis ${ }^{\circledR}$ translates into in vivo antitumor activity. 22RV1 (prostate), SW780 (bladder), Hs746t (gastric), and Mia PaCa-2 (pancreas) cells were xenografted into the right flank of athymic nu/nu mice. Once the tumors 
reached ca. $150 \mathrm{~mm}^{3}$, the mice were randomized into groups of 10 and Zalypsis ${ }^{\circledR}$ was intravenously administered either in 3 consecutive weekly doses $(0.9 \mathrm{mg} / \mathrm{kg} / \mathrm{day})$ (prostate and bladder) or in 2 cycles of 5 consecutive daily doses $(0.3 \mathrm{mg} / \mathrm{kg} /$ day) (gastric and pancreas). Control animals received an equal volume of vehicle. At the drug doses used in the experiment, no significant toxicity or body weight loss was observed in the treated animals. Tumors in mice treated with Zalypsis ${ }^{\circledR}$ as a single agent strongly reduced their proliferation over the assay period, which finished when paired vehicle-treated animals had to be sacrificed (Figure 4). Tumor growth reduction ranged from $69 \%$ in the Hs746t gastric cancer cell line to $42 \%$ in the MiaPaCa-2 pancreas cancer cell line. Tumor growth reductions in the 22RV1 (human prostate cancer), and SW780 (human bladder cancer) xenografts treated with Zalypsis ${ }^{\circledR}$ were $63 \%$ and $55 \%$, respectively. The differences in tumor volumes between the vehicle- and the Zalypsis ${ }^{\circledR}{ }_{-}$ treated cohorts were statistically significant $(p<0.05)$ from Day 16 (22RV1, prostate), Day 24 (SW780, bladder), Day 19 (Hs746t, gastric) and Day 22 (Mia PaCa-2, pancreas) until the end of the experiments (Figure 4).

\section{Discussion}

In the present work we introduce Zalypsis ${ }^{\circledR}$, a new synthetic tetrahydroisoquinoline alkaloid that induces DNA damage and apoptosis in a variety of cancer cell lines in the low nanomolar range and shows a potent antitumor activity in several mouse xenograft models.

We first investigated whether Zalypsis ${ }^{\circledR}$ was able to bind either naked or methylated DNA through band shift assays, a methodology that has been previously used for similar analysis with other alkylating agents $[13,15,20]$. Zalypsis ${ }^{\circledR}$ was able to bind to both a naked PCR product of $250 \mathrm{bp}$ with multiple guanines spread over its whole length and an oligonucleotide with a single binding site. This binding was dependent on the presence of the reactive carbinolamine moiety in the drug since ET-745, a related compound without this reactive group, 
did not produce any band shifts at any of the concentrations tested. Furthermore, Zalypsis ${ }^{\circledR}$ was able to bind to guanines that are preceded by a methylated cytosine (CpG natural methylation sites), demonstrating that methylation in the major groove does not affect binding of the drug to the minor groove.

Structurally, Zalypsis ${ }^{\circledR}$ belongs to a family of compounds that bind to the exocyclic amino group of guanines in the DNA double helix through an iminium intermediate generated in situ by dehydration of the carbinolamine moiety present in the A-ring $[4,6-8]$. The resulting adduct is additionally stabilized through van der Waals interactions and the establishment of one or more hydrogen bonds with surrounding nucleotides [8, 9, 21]. In fact, hydrogen bonding rules seem to determine the binding sequence specificity of the tetrahydroisoquinoline family of drugs $[9,15]$. Considering the diversity of regulatory mechanisms that rely on specific DNA sequences, it can be speculated that sequence selectivity may drive therapeutic specificity for the different DNAbinding compounds. Thus, while guanines are the target of many agents that alkylate DNA, anthramycin selects $\mathrm{A} \underline{\mathrm{G}} \mathrm{A}$ and $\mathrm{A} \underline{\mathrm{GG}}$ triplets [22]; saframycins prefer $\mathrm{G} \underline{\mathrm{G}}$ or $\mathrm{G} \underline{\mathrm{G}} \mathrm{C}$ [23];

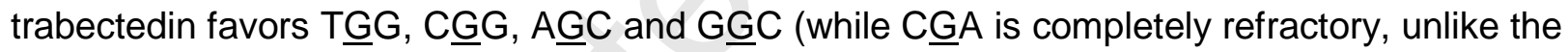
N12-demethylated analogue ET-729 [15]), and Zalypsis ${ }^{\circledR}$ is shown here to have a preference

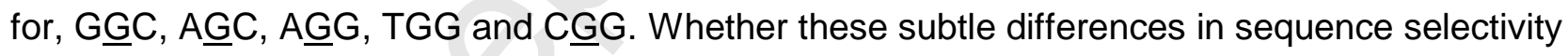
may eventually generate differences in activity against diverse tumor types, is presently not known. On the other hand, the average DNA stabilization brought about on the double helix by drug binding $\left(\Delta \mathrm{T}_{\mathrm{m}}(\max )\right)$ was different for Zalypsis ${ }^{\circledR}\left(\sim 10^{\circ} \mathrm{C}\right)$ compared to Yondelis ${ }^{\circledR}\left(\sim 20^{\circ} \mathrm{C}\right)$ (supplementary Figure 1) [10] although it is still as high as that caused by a tight-binding bisintercalating agent such as echinomycin or thiocoraline [14]. The differences in reactivity and stabilization found for the rather comprehensive collection of alternative DNA triplets containing a central guanine could be rationalized on the basis of molecular models that showed the importance of specific hydrogen-bonding interactions involving drug and DNA atoms in the 
minor groove for attaining a suitable geometry for nucleophilic attack and covalent adduct formation.

We then verified that Zalypsis ${ }^{\circledR}$ induces DSBs in human cancer cells other than those from multiple myeloma for which $\mathrm{y}-\mathrm{H} 2 \mathrm{AX}$ foci formation following exposure to this compound has been recently reported [24]. Indeed, our data show that drug treatment at nanomolar concentrations for 6 hours gives rise to a high proportion of positive cells with abundant $\mathrm{Y}-\mathrm{H} 2 \mathrm{AX}$ foci per cell, as well as comets with a considerable percentage of DNA in the tail. Taken together, these findings most likely indicate that the Zalypsis ${ }^{\circledR}$-DNA adducts are eventually transformed into DSBs in replicating cells. This is not surprising in light of similar findings recently reported for Yondelis ${ }^{\circledR}$ [10] but there still might be some differences in the way both compounds induce these DSBs . In fact, it has already been demonstrated that in Yondelis ${ }^{\circledR}$ treated cells, stalling of the Transcription-Coupled NER (TC-NER) machinery at the adduct position is largely responsible for the toxicity of the compound [25, 26]. In this action, the C-ring present in Yondelis ${ }^{\circledR}$, which protrudes from the DNA minor groove, has been proposed to be directly involved in a hydrogen-bonding interaction with a key basic residue of the NER endonuclease XPG [27]. Since the ring in Zalypsis ${ }^{\circledR}$ that sticks out of the DNA minor groove is very different, this type of interaction may not take place and the repair complex can be stalled at a different step or even proceed further allowing in this case the effective repair of the DNA adducts. Preliminary data support this view as fission yeast mutants defective in the XPG orthologue Rad13 have been shown to be partially resistant to Yondelis ${ }^{\circledR}$ but not to Zalypsis ${ }^{\circledR}$ [28]. We can then envisage the possibility that Zalypsis ${ }^{\circledR}$ behaves as other alkylating/crosslinking agents giving rise to DNA adducts that escape repair by the NER machinery and eventually lead to replication fork stalls in the S-phase, followed by translesion synthesis (TLS) and generation of DSBs (reviewed in [29]). Moreover, the recent finding that Zalypsis ${ }^{\circledR}$ inhibits transcription with a higher potency than Yondelis ${ }^{\circledR}[11,12]$ may indicate that 
this latter drug principally targets TC-NER-dependent DNA repair whereas Zalypsis ${ }^{\circledR}$ blocks transcription through a stalled initiation or early elongation complex.

In this regard, the data presented here show that Zalypsis ${ }^{\circledR}$ induces an S-phase arrest at both low and high nanomolar concentrations. During S-phase, cells are continuously checking the integrity of their DNA to ensure the accuracy of the copying process. If any alteration is found, there are two safety mechanisms (DNA damage and DNA replication checkpoints) that stop Sphase progression and coordinate the repair of damaged DNA [29-31]. Thus, our data suggest that DNA damage induced by this drug arrests cells in S-phase and activates the DNA replication checkpoints. This scenario is different from that obtained in multiple myeloma cells where Zalypsis ${ }^{\circledR}$ treatment was described to induce an increased in the $G_{0} / G_{1}$ phase [24]. Whether these effects are cell line-or disease-dependent is presently not known. In our experiments, the S-phase accumulation was higher at $15 \mathrm{nM}$ than at $150 \mathrm{nM}$. Probably, this is due to a higher cell survival rate at the lower concentration. In fact, although some of the cells treated with high concentrations of Zalypsis ${ }^{\circledR}$ would still accumulate in S-phase, most of them would stop in the cell cycle phase in which they originally were at the onset of drug treatment, due to the high amount of DNA damage that they endure, and they would die with a slower kinetics. Our data also show that Zalypsis ${ }^{\circledR}$-induced cell death presents the characteristics of apoptosis, with chromatin condensation, dependence on caspase activity and cleavage of the caspase targets PARP-1 and cytokeratin 18. This is in accordance with data obtained in multiple myeloma cell lines on which Zalypsis ${ }^{\circledR}$ treatment induced a strong apoptotic response that was partially dependent on caspase activation [24].

When assayed in a panel of 24 cancer cell lines, Zalypsis ${ }^{\circledR}$ demonstrated a potent cytotoxic activity, with an average $\mathrm{IC}_{50}$ of $7 \mathrm{nM}$ in most cell lines, with the notable exception of HCT116 and CAKI-1, both of which are substantially less sensitive to the drug. Myeloma cell lines have also been recently shown to be highly sensitive to Zalypsis ${ }^{\circledR}$, with $I C_{50}$ values ranging from 
picomolar to low nanomolar concentrations [24]. Other alkaloids of the tetrahydroisoquinoline family, including jorumycin, renieramycins and saframycins, have been previously shown to possess strong cytotoxic activity, with $\mathrm{IC}_{50} \mathrm{~S}$ also in the low nanomolar range $[3,32,33]$. According to our data, Zalypsis ${ }^{\circledR}$ exhibits higher cytotoxic activity against leukemia and stomach tumor cell lines, with breast cancer cell lines being less sensitive than the average. This tissue/cell-type sensitivity pattern is clearly different from that observed for Yondelis ${ }^{\circledR}$ as this ecteinascidin shows selectivity against sarcoma, breast, ovary and lung tumor cell lines, with head-and-neck and colon tumor cell lines being slightly less sensitive [34, 35].

Finally, the in vitro cytotoxicity of Zalypsis ${ }^{\circledR}$ translated well into antitumor activity in vivo in four xenograft models of human cancer. The models analyzed corresponded to cell lines ranging from slightly more sensitive (Hs746T, gastric cancer) to substantially less sensitive (SW780, bladder cancer) than the average in the in vitro cytotoxicity assays. Zalypsis ${ }^{\circledR}$ demonstrated a clear antitumor activity that was highest for the Hs746t gastric cancer model, with a tumor growth reduction of $69 \%$. The pancreatic cancer model MiaPaCa was the least sensitive to Zalypsis ${ }^{\circledR}$ but, even in this case, the compound achieved a $42 \%$ tumor growth reduction. When we assayed the maximum tolerated dose of the drug in two different administration regimes no significant differences among them and no toxic effects to the animals were observed.

In summary, we have demonstrated highly potent in vitro and in vivo anticancer activities of Zalypsis $^{\circledR}$ and gained some insight into its molecular mechanism of action. This agent exerts its anticancer effects through the covalent modification of guanines in the DNA minor groove that eventually give rise to DNA double-strand breaks, S-phase arrest and apoptosis in cancer cells. These encouraging results strongly support its development as a novel anticancer agent with a view to a wide spectrum of clinical settings.

\section{References}


1. Fontana AC, P.; Wahidullah, S.; Naik, C.G.; Cimino, G, A New Antitumor Isoquinoline Alkaloid from the Marine Nudibranch Jorunna funebris. Tetrahedron 2000; 56:7305-8. .

2. Frinke JM and Faulkner DJ, Antimicrobial Metabolites of the Sponge Reniera sp. J. Am. Chem. Soc. 1982; 104:265-9.

3. Oku N, Matsunaga S, van Soest RW and Fusetani N, Renieramycin J, a highly cytotoxic tetrahydroisoquinoline alkaloid, from a marine sponge Neopetrosia sp. J Nat Prod 2003; 66:1136-9.

4. Kishi K, Yazawa K, Takahashi K, Mikami Y and Arai T, Structure-activity relationships of saframycins. J Antibiot 1984; 37:847-52.

5. Rinehart K, Holt TG, Fregeau NL, Stroh JG, Keifer PA, Sun F, li LH and Martin DG, Ecteinascidins 729, 743, 745, 759A, 759B and 770: potent antitumor agents from the Caribean tunicate Ecteinascidia turbinata. J Org Chem 1990; 55: 4512-5.

6. Guan Y, Sakai R, Rinehart K and Wang AH, Molecular and Crystal Structures of Ecteinascidins: Potent Antitumor Compounds from the Caribbean Tunicate Ecteinascidia turbinata. J Biomol Struct Dyn 1993; 10: 793-818.

7. Pommier Y, Kohlhagen G, Bailly C, Waring M, Mazumder A and Kohn KW, DNA sequence- and structure-selective alkylation of guanine N2 in the DNA minor groove by ecteinascidin 743, a potent antitumor compound from the Caribbean tunicate Ecteinascidia turbinata. Biochemistry 1996.; 35: 13303-9.

8. Moore BM, Seaman FC and Hurley LH, NMR-based model of an Ecteinascidin 743-DNA adduct. J. Am. Chem. Soc. 1997; 119:5475-6.

9. Seaman FC and Hurley $\mathrm{LH}$, Molecular basis for the DNA sequence selectivity of ecteinascidin 736 and 743: evidence for a dominant role of direct readout via hydrogen bonding. J Am Chem Soc 1998; 120:13028-41. 
10. Casado JA, Rio P, Marco E, Garcia-Hernandez V, Domingo A, Perez L, Tercero JC, Vaquero JJ, Albella B, Gago F and Bueren JA, Relevance of the Fanconi anemia pathway in the response of human cells to trabectedin. Mol Cancer Ther 2008; 7:130918.

11. Magro P, Alvarez E, Kolb E, Mandola M and Scotto KW, Characterization of tumor cell response to the novel anti-tumor agent Zalypsis®. In: 98th AACR Annual Meeting, Los Angeles, CA, Apr 14-182007, pp. 1529.

12. Feuerhahn S, Mechanistic insights into the effect of oxidative lesions and anticancer drugs on RNA pol II transcription and transcription coupled repair. In: Unité 596 Inserm "Institut de génétique et de biologie moléculaire et cellulaire", Université Louis Pasteur Strasbourg I, Strasbourg, 2008. pp. 148.

13. David-Cordonnier MH, Gajate C, Olmea O, Laine W, de la Iglesia-Vicente J, Perez C, Cuevas C, Otero G, Manzanares I, Bailly C and Mollinedo F, DNA and non-DNA targets in the mechanism of action of the antitumor drug trabectedin. Chem Biol 2005;12:120110.

14. Negri A, Marco E, Garcia-Hernandez V, Domingo A, Llamas-Saiz AL, Porto-Sanda S, Riguera R, Laine W, David-Cordonnier MH, Bailly C, Garcia-Fernandez LF, Vaquero JJ and Gago F, Antitumor activity, X-ray crystal structure, and DNA binding properties of thiocoraline A, a natural bisintercalating thiodepsipeptide. J Med Chem 2007; 50:332233.

15. Marco E, David-Cordonnier MH, Bailly C, Cuevas C and Gago F, Further insight into the DNA recognition mechanism of trabectedin from the differential affinity of its demethylated analogue ecteinascidin ET729 for the triplet DNA binding site CGA. J Med Chem 2006; 49:6925-9. 
16. Redon C, Pilch D, Rogakou E, Sedelnikova O, Newrock K and Bonner W, Histone H2A variants H2AX and H2AZ. Curr Opin Genet Dev 2002; 12:162-9.

17. Guirouilh-Barbat J, Redon C and Pommier Y, Transcription-coupled DNA Double-Strand Breaks Are Mediated via the Nucleotide Excision Repair and the Mre11-Rad50-Nbs1 Complex. Mol Biol Cell, 2008; in press.

18. Norbury CJ and Zhivotovsky B, DNA damage-induced apoptosis. Oncogene 2004; 23: 2797-808.

19. Kramer G, Erdal H, Mertens HJ, Nap M, Mauermann J, Steiner G, Marberger M, Biven K, Shoshan MC and Linder S, Differentiation between cell death modes using measurements of different soluble forms of extracellular cytokeratin 18. Cancer Res $2004 ; 64: 1751-6$.

20. David-Cordonnier MH, Laine W, Lansiaux A, Rosu F, Colson P, de Pauw E, Michel S, Tillequin F, Koch M, Hickman JA, Pierre A and Bailly C, Covalent binding of antitumor benzoacronycines to double-stranded DNA induces helix opening and the formation of single-stranded DNA: unique consequences of a novel DNA-bonding mechanism. Mol Cancer Ther 2005; 4:71-80.

21. Garcia-Nieto R, Manzanares I, Cuevas C and Gago F, Bending of DNA upon Binding of Ecteinascidin 743 and Phthalascidin 650 Studied by Unrestrained Molecular Dynamics Simulations. J. Am. Chem. Soc. 2000; 122:7172-82.

22. Pierce JR, Nazimiec M and Tang MS, Comparison of sequence preference of tomaymycin- and anthramycin-DNA bonding by exonuclease III and lambda exonuclease digestion and UvrABC nuclease incision analysis. Biochemistry 1993; 32:7069-78.

23. Rao KE and Lown JW, DNA sequence selectivities in the covalent bonding of antibiotic saframycins $M x 1, M x 3, A$, and S deduced from MPE.Fe(II) footprinting and exonuclease III stop assays. Biochemistry 1992; 31:12076-82. 
24. Ocio EM, Maiso P, Chen X, Garayoa M, Alvarez-Fernandez S, San-Segundo L, Vilanova D, Lopez-Corral L, Montero JC, Hernandez-Iglesias T, de Alava E, Galmarini C, Aviles P, Cuevas C, San-Miguel JF and Pandiella A, Zalypsis: A novel marine-derived compound with potent antimyeloma activity that reveals high sensitivity of malignant plasma cells to DNA double strand breaks. Blood, 2008.

25. Erba E, Bergamaschi D, Bassano L, Damia G, Ronzoni S, Faircloth GT and D'Incalci M, Ecteinascidin-743 (ET-743), a natural marine compound, with a unique mechanism of action. Eur J Cancer 2001; 37:97-105,

26. Takebayashi Y, Pourquier P, Zimonjic DB, Nakayama K, Emmert S, Ueda T, Urasaki Y, Kanzaki A, Akiyama SI, Popescu N, Kraemer KH and Pommier Y, Antiproliferative activity of ecteinascidin 743 is dependent upon transcription-coupled nucleotide-excision repair. Nat Med 7(8): 961-6, 2001.

27. Herrero AB, Martin-Castellanos C, Marco E, Gago F and Moreno S, Cross-talk between nucleotide excision and homologous recombination DNA repair pathways in the mechanism of action of antitumor trabectedin. Cancer Res 2006; 66:8155-62..

28. Herrero A, Marco E, García-Hernández V, Martín-Castellanos C, Domingo A, Alvarez E, Moreno S and Gago F, Resilience of the cytotoxic effects of Zalypsis® (pm00104) to the lack of a functional nucleotide excision repair system. In: American Association for Cancer Research Annual Meeting, Los Angeles, CA, Apr 14-18, 2007. A3470.

29. Andreassen PR, Ho GP and D'Andrea AD, DNA damage responses and their many interactions with the replication fork. Carcinogenesis 2006; 27:883-92.

30. Zhou BB and Elledge SJ, The DNA damage response: putting checkpoints in perspective. Nature 2000; 408:433-9.

31. Hakem R, DNA-damage repair; the good, the bad, and the ugly. Embo J 2008; 27:589605. 
32. Arai T, Takahashi K, Nakahara S and Kubo A, The structure of a novel antitumor antibiotic, saframycin A. Experientia 1980; 36:1025-7.

33. Lane JW, Estevez A, Mortara K, Callan O, Spencer JR and Williams RM, Antitumor activity of tetrahydroisoquinoline analogues 3-epi-jorumycin and 3-epi-renieramycin G. Bioorg Med Chem Lett 2006; 16:3180-3.

34. Poindessous V, Koeppel F, Raymond E, Comisso M, Waters SJ and Larsen AK, Marked activity of irofulven toward human carcinoma cells: comparison with cisplatin and ecteinascidin. Clin Cancer Res 2003; 9:2817-25.

35. Koeppel F, Poindessous V, Lazar V, Raymond E, Sarasin A and Larsen AK, Irofulven cytotoxicity depends on transcription-coupled nucleotide excision repair and is correlated with XPG expression in solid tumor cells. Clin Cancer Res 2004; 10:5604-13. 
Table 1. Cytotoxicity of Zalypsis ${ }^{\circledR}$ in a panel of 24 human cancer cell lines*.

\begin{tabular}{|c|c|c|c|}
\hline & Cell line & $\mathrm{IC}_{50}(\mathrm{nM})$ & Tissue Average (nM) \\
\hline \multirow[t]{2}{*}{ Prostate } & PC3 & $2.4 \pm 1.1$ & $2.1 \pm 0.4$ \\
\hline & 22RV1 & $1.7 \pm 0.8$ & \\
\hline \multirow[t]{2}{*}{ Pancreas } & PANC-1 & $4.1 \pm 0.8$ & $2.7 \pm 1.9$ \\
\hline & MiaPaCa-2 & $1.3 \pm 0.4$ & \\
\hline \multirow[t]{2}{*}{ Ovary } & IGROV-1 & $3.5 \pm 0.1$ & $2.8 \pm 0.9$ \\
\hline & A2780 & $2.1 \pm 1.3$ & \\
\hline \multirow[t]{3}{*}{ Lung } & $\mathrm{NCl}-\mathrm{H} 460$ & $3 \pm 1.2$ & $2.5 \pm 0.4$ \\
\hline & $\mathrm{NCl}-\mathrm{H} 23$ & $2.2 \pm 0.3$ & \\
\hline & A549 & $2.4 \pm 0.8$ & \\
\hline \multirow[t]{2}{*}{ Liver } & SK-HEP-1 & $2.5 \pm 0.8$ & $2.5 \pm 0.1$ \\
\hline & HEPG2 & $2.6 \pm 1.5$ & \\
\hline \multirow[t]{2}{*}{ Leukemia } & MOLT4 & $0.5 \pm 0.2$ & $1 \pm 0.7$ \\
\hline & K562 & $1.6 \pm 1.5$ & \\
\hline \multirow[t]{2}{*}{ Kidney } & RXF393 & $2.1 \pm 0.5$ & $21.9 \pm 27$ \\
\hline & CAKI-1 & $41 \pm 5$ & \\
\hline \multirow[t]{2}{*}{ Stomach } & HS746T & $1.5 \pm 0.1$ & $1.6 \pm 0.07$ \\
\hline & HGC-27 & $1.6 \pm 0.5$ & \\
\hline \multirow[t]{3}{*}{ Colon } & LoVo & $2.4 \pm 0.8$ & $23 \pm 34$ \\
\hline & HT29 & $3.8 \pm 0.2$ & \\
\hline & НCT-116 & $62 \pm 30$ & \\
\hline Bladder & SW780 & $10 \pm 0$ & 10 \\
\hline \multirow[t]{3}{*}{ Breast } & MDA-MB-231 & $4.8 \pm 0.8$ & $4.1 \pm 0.9$ \\
\hline & MCF-7 & $4.5 \pm 0.1$ & \\
\hline & BT-474 & $3 \pm 1.2$ & \\
\hline
\end{tabular}

* Values represent mean \pm SD of three different experiments 
Table 2. Cell cycle perturbations ${ }^{*}$ induced by Zalypsis ${ }^{\circledR}$

\begin{tabular}{|c|c|c|c|c|}
\hline & Cell cycle phase & Control & $15 \mathrm{nM}$ & $150 \mathrm{nM}$ \\
\hline \multirow[t]{4}{*}{ A549 } & Sub-G ${ }_{1}$ & 1.7 & 13 & 5.7 \\
\hline & $\mathrm{G}_{0} / \mathrm{G}_{1}$ & 60 & 24 & 49 \\
\hline & S-phase & 25 & 49 & 30 \\
\hline & $\mathrm{G}_{2} / \mathrm{M}$ & 8.6 & 7.6 & 7.1 \\
\hline \multirow[t]{4}{*}{ HT29 } & Sub-G ${ }_{1}$ & 0.3 & 15 & 21 \\
\hline & $\mathrm{G}_{0} / \mathrm{G}_{1}$ & 64 & 17 & 38 \\
\hline & S-phase & 38 & 63 & 36 \\
\hline & $G_{2} / M$ & 2 & 9.2 & 3.8 \\
\hline \multirow[t]{4}{*}{ MDA-MB-231 } & Sub-G ${ }_{1}$ & 2.3 & 2.2 & 7 \\
\hline & $\mathrm{G}_{0} / \mathrm{G}_{1}$ & 37 & 12 & 23.3 \\
\hline & S-phase & 30 & 47 & 33 \\
\hline & $\mathrm{G}_{2} / \mathrm{M}$ & 13 & 22 & 18 \\
\hline \multirow[t]{4}{*}{ IGROV-1 } & Sub-G ${ }_{1}$ & 2.8 & 56 & 68 \\
\hline & $\mathrm{G}_{0} / \mathrm{G}_{1}$ & 39 & 11 & 6.5 \\
\hline & S-phase & 33 & 21 & 18 \\
\hline & $\mathrm{G}_{2} / \mathrm{M}$ & 16 & 8.5 & 1.7 \\
\hline
\end{tabular}

* Cells were treated with the appropriate amount of the compound for $24 \mathrm{~h}$, and then stained with $0.4 \mu \mathrm{g} / \mathrm{ml}$ propidium iodide. Samples were analyzed with a FACScalibur flow cytometer (Beckton and Dickinson, Frankin Lakes, NJ, USA) and the FlowJo7 cytometry analysis software. Values represent \% of cells in each phase of the cell cycle. 


\section{LEGENDS TO FIGURES}

Figure 1. Cytotoxic effect and DNA Binding properties of Zalypsis ${ }^{\circledR}$. A: Structure of Zalypsis ${ }^{\circledR}$ showing the positions of $C 21$ and $N 12$ atoms discussed on the main text. B: Binding to naked DNA. Drugs were incubated with a naked $250 \mathrm{bp} \mathrm{PCR}$ product at $25^{\circ} \mathrm{C}$ during 1 hour and the electrophoresis run in $2 \%$ agarose-TAE. C: Binding to methylated DNA. The methylated ds-oligo with a unique binding site for Zalypsis ${ }^{\circledR}$ was incubated with the drug at $25^{\circ} \mathrm{C}$ during 1 hour, then electrophoresis was run in a $20 \%$ acrylamide-TAE gel.

Figure 2. Characteristics and modeling of DNA-Zalypsis ${ }^{\circledR}$ complexes. A: Relative binding affinities for different DNA triplet sequences. Zalypsis ${ }^{\circledR}$ was incubated with the labeled ds-oligos at $25^{\circ} \mathrm{C}$ during 1 hour, then the melting assay was started in a 7500 Fast Real-Time PCR System by increasing the temperature up to $95^{\circ} \mathrm{C}$ in small steps of $1^{\circ} \mathrm{C} \mathrm{min}{ }^{-1}$. Analysis of the $1 / C_{50}$ parameter was done with an in-house developed Visual Basic Application (VBA) running on Microsoft Excel. An additional parameter, $\Delta \mathrm{T}_{\mathrm{m}}(\max )$, which is related to the stability of the drug-DNA complex, was also analyzed using the VBA. The values correspond to the mean and standard deviation from at least two independent experiments for each sequence. B: View of the central part of the precovalent Zalypsis ${ }^{\circledR}: A G C$ model complex in which a semitransparent solvent-accessible surface envelops the DNA atoms. Drug and DNA carbon atoms have been colored cyan and green, respectively. Only hydrogens attached to N12 and O21 of Zalypsis ${ }^{\circledR}$ and the amino groups of G8 and G20 are shown. Crucial hydrogen bonds are displayed as dotted yellow lines for the drug-DNA complex and dashed black lines for the DNA base pairs. C: Attacking distances and relevant intermolecular distances $(\AA)$ between hydrogen-bonding donor and acceptor atoms in the three precovalent complexes studied (the italics for the AGA complex highlight longer distances than those needed to establish a hydrogen bond). 
Figure 3. Zalypsis ${ }^{\circledR}$ treatment induces DNA double-strand breaks and apoptosis in living cells. A: A549 or MCF7 cells were treated with the drug at the indicated concentrations during 6 hours, followed by additional 18 hours of incubation without the drug. After fixation, cells were immunostained for $\mathrm{y}-\mathrm{H} 2 \mathrm{AX}$ and nuclei were visualized with Hoestch 33342. B: Zalypsis ${ }^{\circledR}$-treated cells were simultaneously analyzed through comet assay to determine the amount of DSBs induced by the drug. After 12 hours of treatment with the indicated concentrations of Zalypsis ${ }^{\circledR}$, cells were washed with PBS, detached mechanically and included in low melting point agarose. After a treatment of lysis, cells were subjected to electrophoresis and the comets were stained with SYBR Green. Quantitation of the amount of DNA in the comets was performed with Photoshop CS3. ${ }^{* *} p<0.001 ;{ }^{* \star *} p<0.0001$. C: Apoptosis induced by Zalypsis ${ }^{\circledR}$ is caspasedependent. A549 cells were treated with the drugs during 24 hours, washed and processed following the protocol of the M30-Apoptosense solid-phase sandwich enzyme immunoassay. D: Caspase activation and PARP-1 processing. MCF7 and A549 cells were treated with Zalypsis ${ }^{\circledR}$ $100 \mathrm{nM}$ during 24 hours and then washed and lysed with RIPA buffer supplemented with a protease inhibitor cocktail. Western blot was then performed using a primary anti-PARP-1 polyclonal antibody.

Figure 4. In vivo antitumor activity of Zalypsis ${ }^{\circledR}$. Treatment with Zalypsis ${ }^{\circledR}$ results in statistically signifcant $\left({ }^{*}, p<0.05\right)$ tumor growth inhibition in 22RV1 prostate $(\boldsymbol{\nabla})$, SW780 bladder $(\triangle)$, Hs746t gastric $(\bigcirc)$, and Mia PaCa-2 pancreas $(\bullet)$ xenograft models compared to vehicle (घ) treated animals. Treatments started at a tumor volume size of ca. $150 \mathrm{~mm}^{3}$ and were intravenously administered in two cycles of either five consecutive daily at $0.3 \mathrm{mg} / \mathrm{kg}$ (prostate and bladder) or 3 consecutive weekly doses at $0.9 \mathrm{mg} / \mathrm{kg}$ (gastric and pancreas). Each point represents mean $\pm S E M$ value $(n=10)$. Arrows indicate dosing days.

\section{Supplementary Figure 1. Structure of ET-745 and ET-743 (Yondeli®).}


A

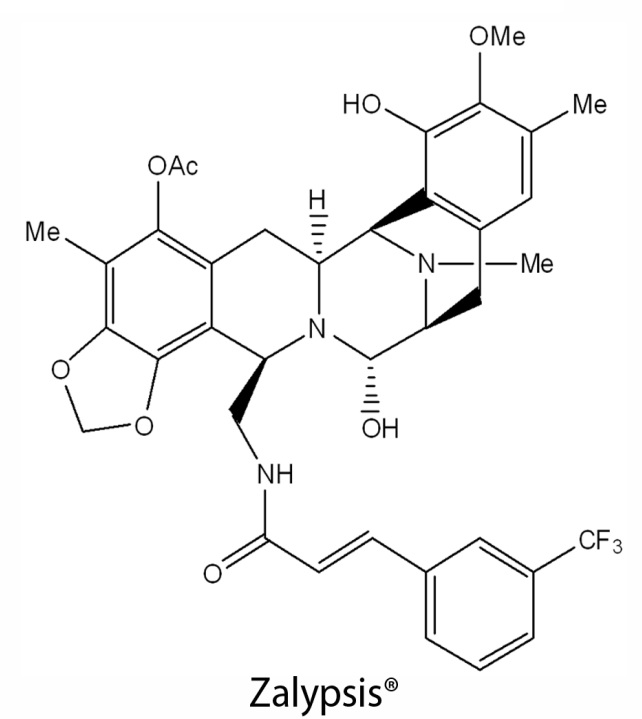

B

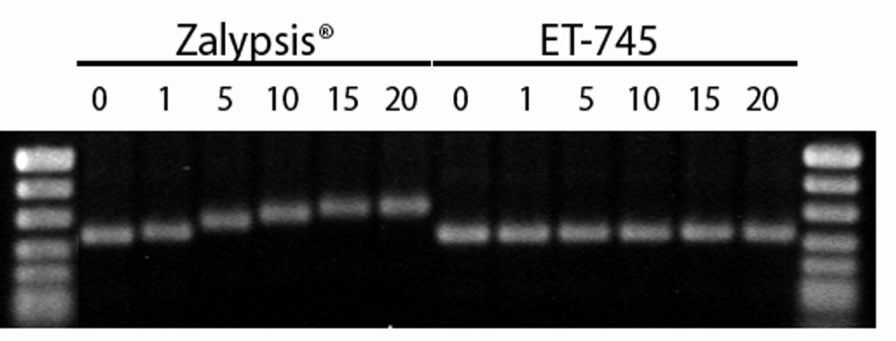

C

Unmethyl Upper Methyl Lower Methyl Double Methyl

\begin{tabular}{llllllllllllll}
\hline 0 & 25 & 125 & 0 & 25 & 125 & 0 & 25 & 125 & & 0 & 25 & 125 & [ $\mu \mathrm{M}]$
\end{tabular}

- 5 -

Leal et al. Figure 1 
A
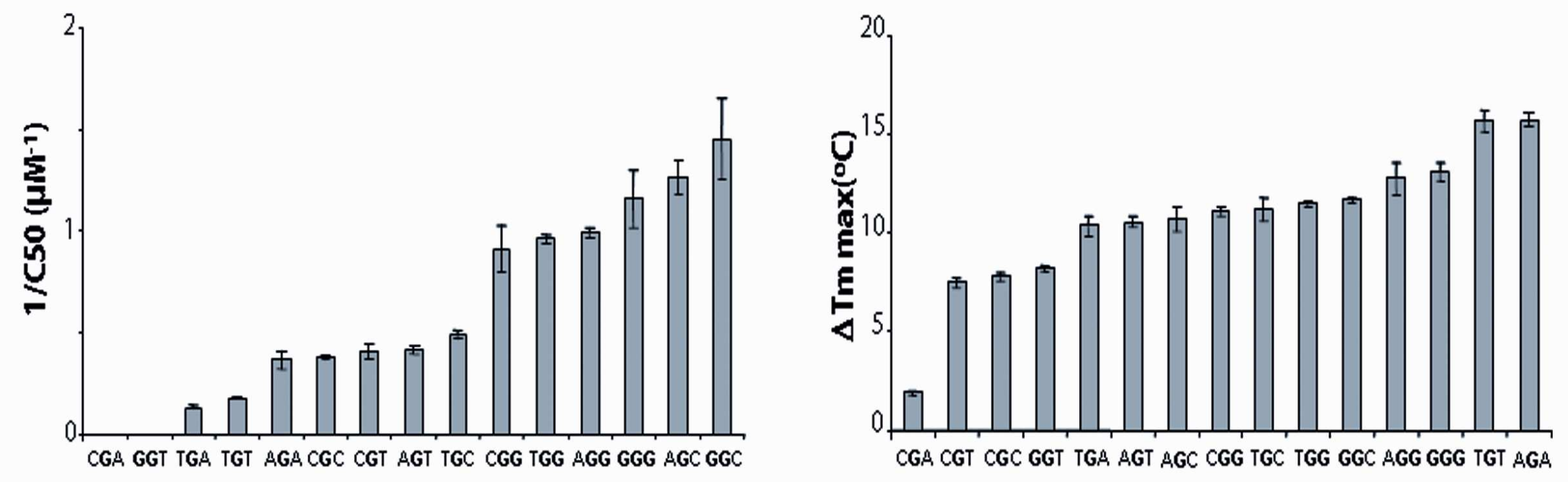

B

C

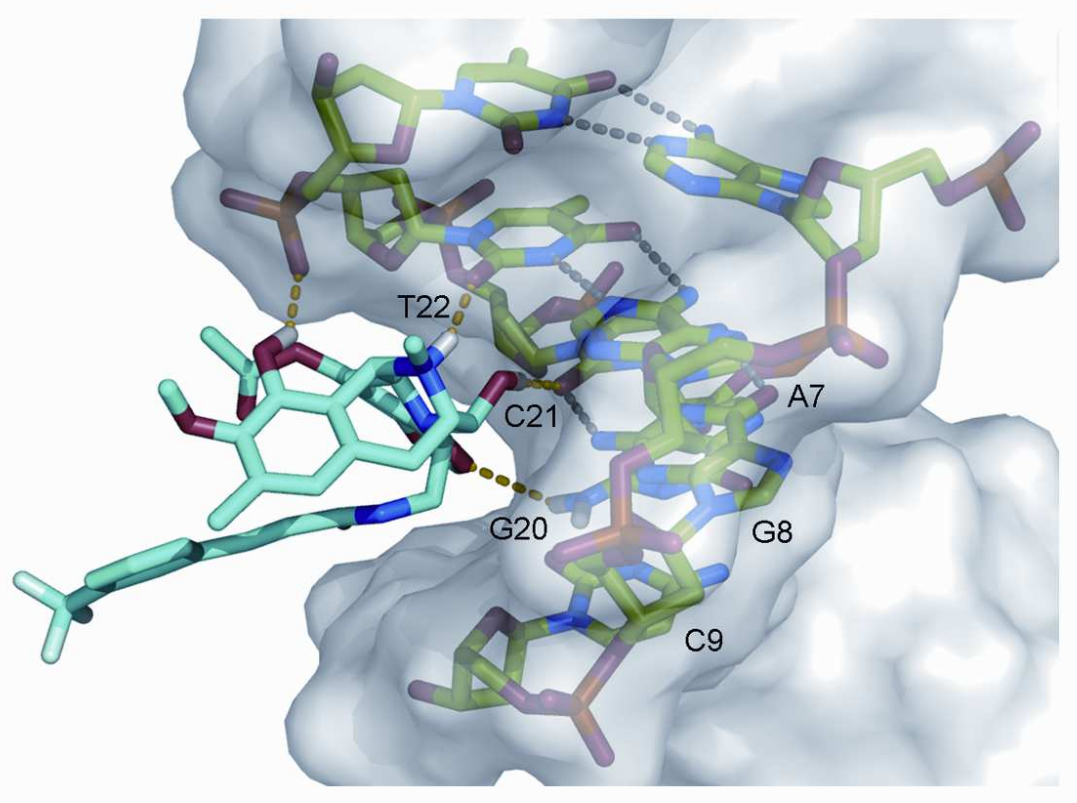

$\begin{array}{cccc} & \text { AGA } & \text { AGG } & \text { AGC } \\ \text { C21-N2 (G8) } & 3.7 \pm 0.5 & 3.8 \pm 0.4 & 3.6 \pm 0.3 \\ \text { OM-N2 (G9) } & - & 3.1 \pm 0.3 & - \\ \text { OM-N2 (G20) } & - & - & 3.2 \pm 0.3 \\ \text { N12-O2 (T22) } & 3.8 \pm 0.4 & 2.8 \pm 0.1 & 2.8 \pm 0.1 \\ \text { OH-O2 (C21) } & 2.7 \pm 0.1 & 2.8 \pm 0.2 & 2.7 \pm 0.1 \\ \text { OH-N2 (G8) } & 3.7 \pm 0.3 & 3.0 \pm 0.2 & 3.0 \pm 0.2 \\ \text { OHC-O1P (T23) } & - & - & 2.6 \pm 0.1\end{array}$

Leal et al. Figure 2 
A
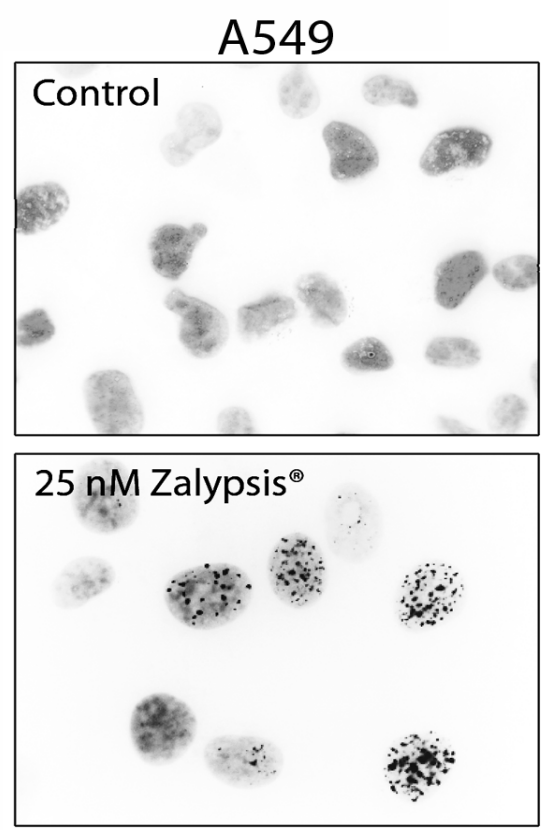

C

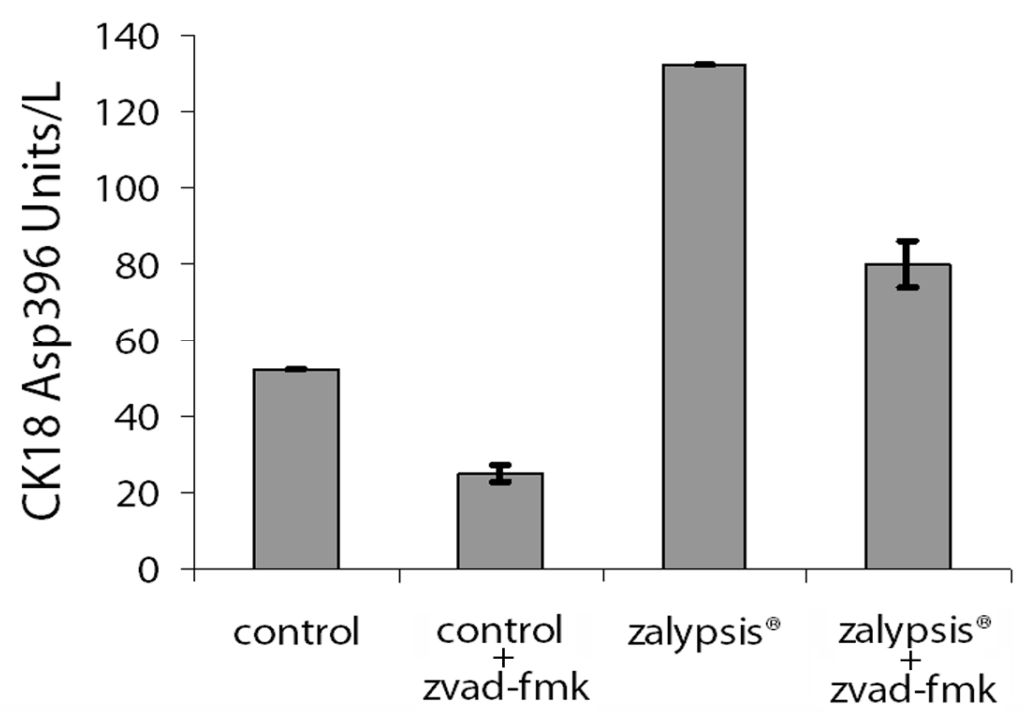

B

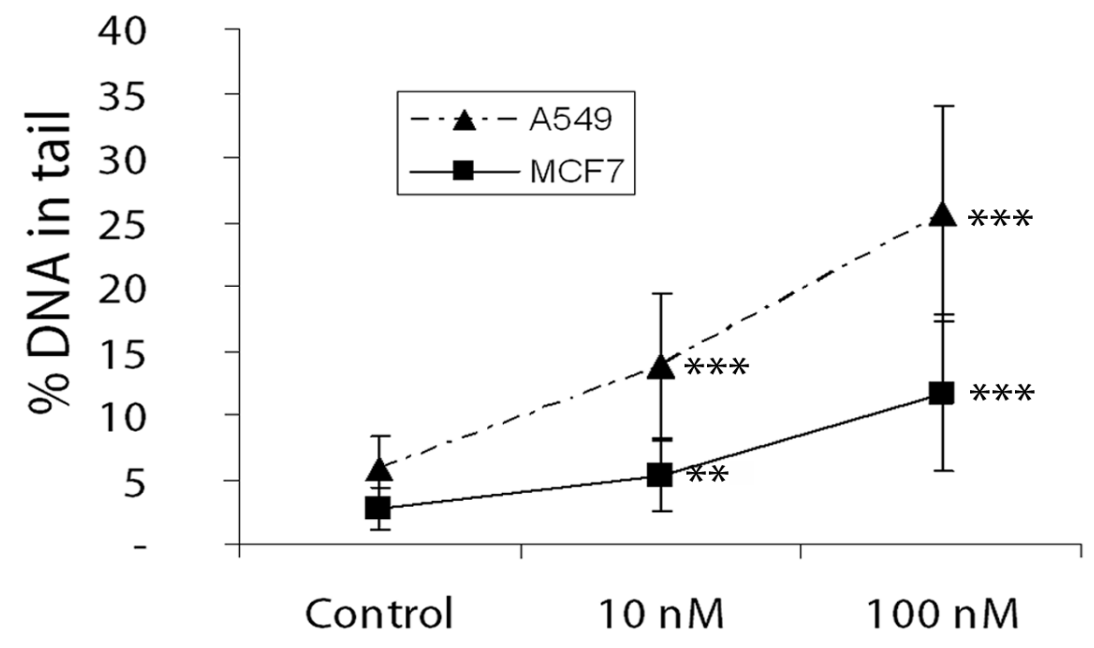

D

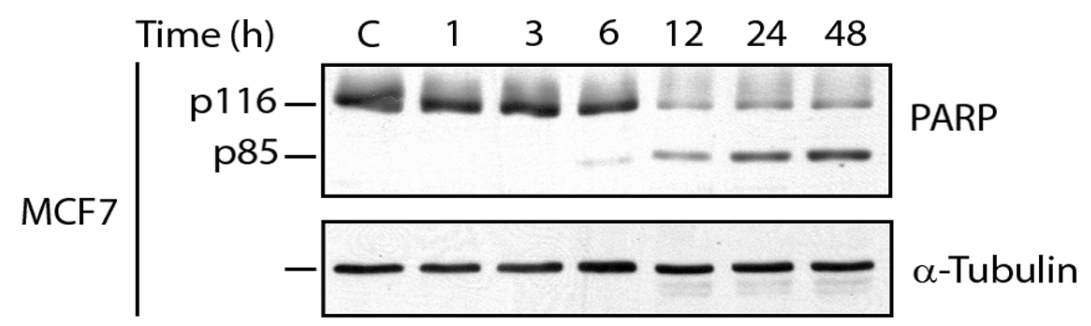

A549

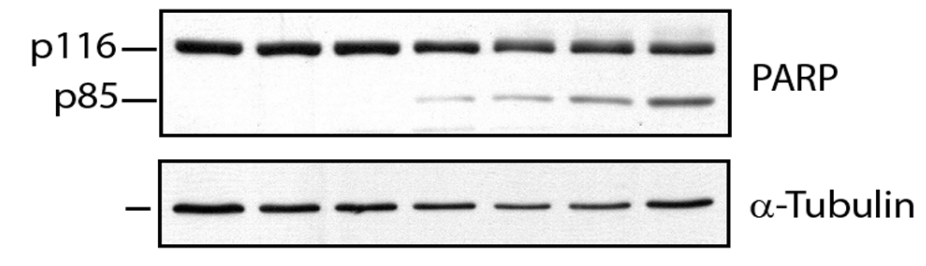

\section{Leal et al. Figure 3}



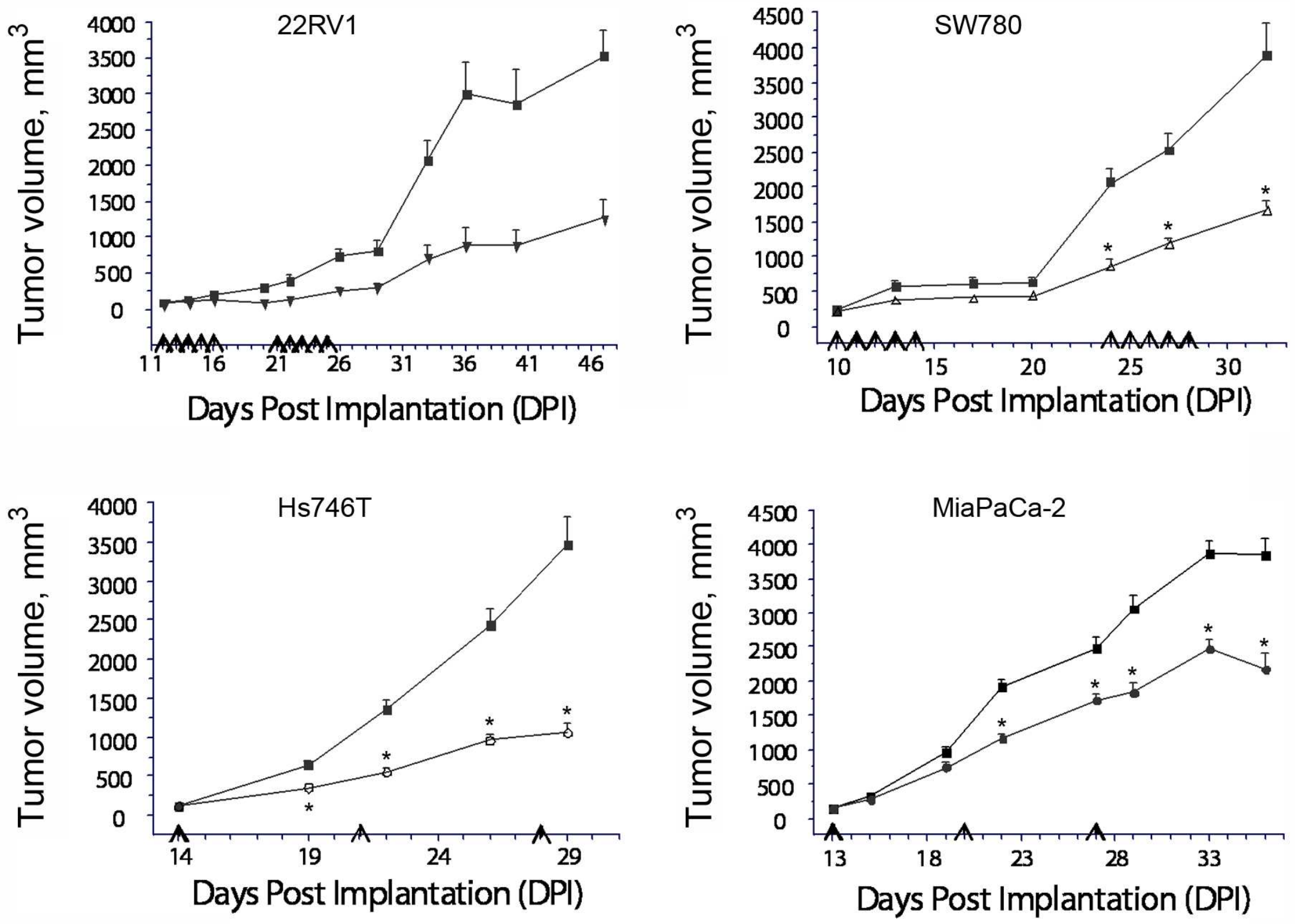

Leal et al. Figure 4 